\title{
Isolation and Serological Survey of Salmonella in Pigs in Japan
}

\author{
Tetsuo ASAI ${ }^{1)}$, Seiichi FUJII ${ }^{1)}$, Takayuki OSUMI ${ }^{1)}$, Yukiko OTAGIRI ${ }^{1)}$, Takanori NAMIMATSU ${ }^{1)}$ and Shizuo SATO ${ }^{1)}$

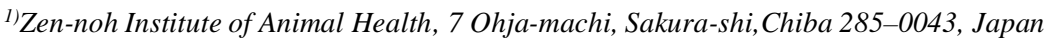

(Received 10 April 2002/Accepted 3 August 2002)

ABSTRACT. A total of 267 fecal and serum samples collected from individual pigs reared on a Salmonella-positive farm were subjected to bacteriological and serological examinations of Salmonella. Salmonella was isolated from 47 pigs (17.6\%) and prevalence of antibody to lipopolysaccharide (LPS) of $S$. Typhimurium, which was partly common to $S$. O4, 12: d: -, was observed in 90 pigs (33.7\%). Salmonella was isolated from 26 (28.9\%) of 90 antibody-positive pigs and 21 (11.9\%) of 177 antibody-negative pigs. Twenty-one of 36 pigs (58.3\%) positive for S. O4, 12: d: -, five of 10 pigs (50.0\%) positive for $S$. Havana, and none for $S$. Anatum had antibodies. Thus, seropositive rates were higher than isolation-positive rates, and antibody prevalence was associated with serovars of the isolates. Then, we analyzed antibody prevalence among pigs on Japanese pig farms. The antibodies to LPS of $S$. Typhimurium were found in 195 of 1,498 pigs $(13.0 \%)$ and in at least one serum sample on 35 of 52 farms (67.3\%). Our results indicate that Salmonella does not seem to be so prevalent in pigs though it is widely prevalent among pig farms.

KEY wORDS: antibody, ELISA, Salmonella, swine.

J. Vet. Med. Sci. 64(11): 1011-1015, 2002

Salmonella is a causative agent of food-borne diseases in humans and its contamination of animal products is a significant implication on public health [4]. To avoid outbreak of food-borne diseases due to meat and eggs, their practitioner and veterinarian should recognize and take care for prevention of infection of domestic animals with food-borne disease related organisms including Salmonella. Generally, to estimate the Salmonella prevalence in pig herds, bacteriological examinations were performed on fecal and clinical tissue samples of pigs $[2,7,13,17]$. Serological examinations by enzyme-linked immunosorbent assay (ELISA) of serum and meat juice were also undertaken in several countries $[9,10,14,15]$. Though serological examination was evaluated in the pigs experimentally infected with Salmonella $[9,12]$, little information on the relation between serological and bacteriological examinations is available in the pigs naturally infected with Salmonella. We encountered a herd contaminated with Salmonella (mainly of O4, 12: d: -). As the O-antigen O4, 12: d: - is partly common to that of $S$. Typhimurium, the serum antibody prevalence in the herd could be tested by ELISA using lipopolysaccharide (LPS) of $S$. Typhimurium as an antigen. So, under the field conditions, we compared the serological examinations with bacteriological examinations. Furthermore, as previous reports have shown that $\mathrm{O} 4$ group is the dominant serovars of Salmonella infecting pigs in Japan [1, 2, 7, 17], we conducted surveillance for the antibody prevalence in the serum samples collected from pigs in Japan.

\section{MATERIALS AND METHODS}

Serological and bacteriological studies in a pig operation (Experiment 1): The herd we surveyed consisted of 800 sows, under continuous farrow-to-finish operation in Japan. According to the previous health inspection, the herd had been infected with Salmonella (O4, 12: d: -, Havana, and
Anatum). Sows were replaced by own-producing gilts on the farm. Bloods and feces were collected from each individual pig. After each sample was transported within $24 \mathrm{hr}$, fecal samples were cultured for isolation of Salmonella. After centrifugation, the serum samples were stored at $-20^{\circ} \mathrm{C}$ until use.

Serological surveys on the pig farms (Experiment 2): A total of 1,498 serum samples were randomly collected from 52 pig farms in 2000 and 2001 . The serum samples were stored at $-20^{\circ} \mathrm{C}$ until use for serological examinations.

Bacteriological examination: Isolation of Salmonella was attempted from fecal samples as previously described $[2,8]$. Serological examinations: Serum antibodies to LPS of $S$. Typhimurium were measured by ELISA, according to the method of Nielsen et al. [9] with slight modification. In brief, commercially available LPS of $S$. Typhimurium (Sigma, Co, Ltd., U.S.A.) was used as the ELISA antigen. From the results of the preliminary examinations, positive wells were coated with $0.1 \mathrm{~m} l$ of $60 \mathrm{ng} / 0.1 \mathrm{~m} l$ of LPS in the coating buffer and negative wells with $0.1 \mathrm{~m} l$ of the coating buffer. After incubation overnight at $4^{\circ} \mathrm{C}$, the plates were washed three times with phosphate-buffered saline (PBS) containing $0.05 \%(\mathrm{v} / \mathrm{v})$ Tween 20 (PBS-T). Fetal bovine serum $(10 \%)$ in PBS-T (PBS-T-FBS) was added to each well for blocking for $1 \mathrm{hr}$ at room temperature (RT) and washed three times. Serum samples were diluted 1:300 in PBS-T-FBS and applied to positive and negative wells for 1 $\mathrm{hr}$ at RT. After three-times washings, $0.1 \mathrm{~m} l$ of diluted horseradish-peroxidase-labeled rabbit anti-pig serum in PBS-T-FBS (Bethyl Laboratories, U.S.A.) was added to each well. The plates were incubated for $1 \mathrm{hr}$ at RT, and then washed three times. One-tenth milliliter of substrate (20 mg of 1-2 orthophenylendiamine dihydrochioride)

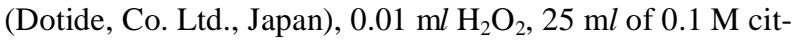
rate, and $25 \mathrm{~m} l$ of $0.2 \mathrm{M} \mathrm{NaH}_{2} \mathrm{PO}_{4}$ were added to each well. After $15 \mathrm{~min}, 0.1 \mathrm{ml}$ of $1 \mathrm{M} \mathrm{H}_{2} \mathrm{SO}_{4}$ was added as a stop solu- 
Table 1. Isolation of Salmonella from pigs on a Salmonella-positive farm and antibody pevalence in the Samonella-isolated pigs

\begin{tabular}{|c|c|c|c|c|c|c|c|c|c|c|}
\hline \multirow{3}{*}{ Stage } & \multirow[b]{3}{*}{$\begin{array}{c}\text { Age } \\
\text { (month) }\end{array}$} & \multirow[b]{3}{*}{$\begin{array}{c}\text { No. of } \\
\text { pigs } \\
\text { tested }\end{array}$} & \multicolumn{6}{|c|}{ Salmoenlla-isolated pigs } & \multirow{2}{*}{\multicolumn{2}{|c|}{ One of serovars }} \\
\hline & & & \multicolumn{2}{|c|}{ S. O4, 12:d:- } & \multicolumn{2}{|c|}{ S. Havana } & \multicolumn{2}{|c|}{ S. Anatum } & & \\
\hline & & & $\begin{array}{l}\text { No. of } \\
\text { pigs }\end{array}$ & $\begin{array}{l}\text { No. of pigs } \\
\text { positive for } \\
\text { antibody }\end{array}$ & $\begin{array}{l}\text { No. of } \\
\text { pigs }\end{array}$ & $\begin{array}{c}\text { No. of pigs } \\
\text { positive for } \\
\text { antibody }\end{array}$ & $\begin{array}{c}\text { No. of } \\
\text { pigs }\end{array}$ & $\begin{array}{l}\text { No. of pigs } \\
\text { positive for } \\
\text { antibody }\end{array}$ & $\begin{array}{c}\text { No. of } \\
\text { pigs (\%) }\end{array}$ & $\begin{array}{l}\text { No. of pigs } \\
\text { positive for } \\
\text { antibody }\end{array}$ \\
\hline \multirow{7}{*}{ Fattening pigs } & 1 & 15 & 0 & 0 & 0 & 0 & 0 & 0 & $0(0)$ & 0 \\
\hline & 2 & 35 & 0 & 0 & 0 & 0 & 0 & 0 & $0(0)$ & 0 \\
\hline & 3 & 35 & 0 & 0 & 0 & 0 & 0 & 0 & $0(0)$ & 0 \\
\hline & 4 & 21 & 6 & 2 & 0 & 0 & 1 & 0 & 7 (33.3) & 2 \\
\hline & 5 & 45 & 7 & 5 & 3 & 1 & 0 & 0 & $10(22.2)$ & 6 \\
\hline & 6 & 22 & 7 & 5 & 0 & 0 & 0 & 0 & $7(31.8)$ & 5 \\
\hline & subtotal & 173 & 20 & 12 & 3 & 1 & 1 & 0 & $24(13.9)$ & 13 \\
\hline Gilts & & 59 & 13 & 7 & 5 & 2 & 0 & 0 & $18(30.5)$ & 9 \\
\hline Sows & & 35 & 3 & 2 & 2 & 2 & 0 & 0 & $5(14.3)$ & 4 \\
\hline Total & & 267 & 36 & 21 & 10 & 5 & 1 & 0 & $47(17.6)$ & 26 \\
\hline
\end{tabular}

Table 2. Comparison of isolation and serological examination in pigs on a Salmonella-positive farm

\begin{tabular}{|c|c|c|c|c|c|c|}
\hline \multirow[t]{2}{*}{ Stage } & \multirow[b]{2}{*}{$\begin{array}{c}\text { Age } \\
\text { (month) }\end{array}$} & \multirow[b]{2}{*}{ Tested } & \multicolumn{2}{|c|}{ Antibody positive } & \multicolumn{2}{|c|}{ Antibody negative } \\
\hline & & & No. of pigs (\%) & $\begin{array}{l}\text { No. of pigs } \\
\text { isolated }\end{array}$ & No. of pigs (\%) & $\begin{array}{l}\text { No. of pigs } \\
\text { isolated }\end{array}$ \\
\hline \multirow[t]{7}{*}{ Fattening pigs } & 1 & 15 & $0(0)$ & 0 & $15(100)$ & 0 \\
\hline & 2 & 35 & $0(0)$ & 0 & $35(100)$ & 0 \\
\hline & 3 & 35 & $6(17.1)$ & 0 & $29(82.9)$ & 0 \\
\hline & 4 & 21 & $2(9.5)$ & 2 & $19(90.5)$ & 5 \\
\hline & 5 & 45 & $14(31.1)$ & 6 & $31(68.9)$ & 4 \\
\hline & 6 & 22 & $10(45.5)$ & 5 & $12(54.5)$ & 2 \\
\hline & subtotal & 173 & $32(18.5)$ & 13 & $141(81.5)$ & 11 \\
\hline Gilts & & 59 & $31(52.5)$ & 9 & $28(47.5)$ & 9 \\
\hline Sows & & 35 & $27(77.1)$ & 4 & $8(22.9)$ & 1 \\
\hline Total & & 267 & $90(33.7)$ & 26 & $177(66.3)$ & 21 \\
\hline
\end{tabular}

tion. The optical density (OD) was read at $490 \mathrm{~nm}$ with a plate reader. ELISA value was calculated as follows; OD of positive well - OD of negative well. In the preliminary study using the sera of primary specific pathogen-free (SPF) pigs, the cut-off value of ELISA value was determined as 0.20 (average $+3 \mathrm{SD}$ ), since the average ELISA value were $0.05 \pm 0.05$.

Statistical analysis: The results were evaluated statistically by the Chi-square test, by Yetes' correlation or by Fisher's exact test.

\section{RESULTS}

Experiment 1: Salmonella was isolated from 47 of 267 pigs $(17.6 \%)$ on a Salmonella-positive farm (Table 1). The age of pigs from which Salmonella was isolated was over 4 month. Seven of 21 pigs $(33.3 \%)$ at 4 months of age, 10 of $45(22.2 \%)$ at 5 months of age, and seven of $22(31.8 \%)$ at 6 months of age were found positive for Salmonella, and 18 of 59 gilts $(30.5 \%)$ and 5 of 35 sows $(14.3 \%)$ were found positive for Salmonella. Salmonella isolates were identified as three different serovars. Out of 47 positive pigs, S. O4, 12: d: - was isolated from $36(76.6 \%), S$. Havana from 10 $(21.3 \%)$, and $S$. Anatum from one $(2.1 \%)$.

Prevalence of antibody to LPS of $S$. Typhimurium was observed in 90 of $267(33.7 \%)$ pigs (Table 2). Six of 35 pigs $(17.1 \%)$, two of $21(9.5 \%), 14$ of $45(31.1 \%)$, and 10 of 22 $(45.5 \%)$ at 3 to 6 months of age, respectively, and 31 of 59 gilts $(52.5 \%)$ and 27 of 35 sows $(77.1 \%)$ were positive. Out of 90 antibody-positive pigs, $26(28.9 \%)$ were positive for isolation. Isolation positive rates were $100 \%(2 / 2), 42.8 \%$ $(6 / 14)$, and $50.0 \%(5 / 10)$ in antibody-positive pigs at 4,5 and 6 months of age, respectively. Salmonella was isolated also from 21 pigs (11.9\%) of 177 antibody-negative pigs. Isolation positive rates were $26.3 \%$ (5/19), $12.9 \%$ (4/31), and $16.7 \%(2 / 12)$ in antibody-negative pigs at 4,5 and 6 months of age, respectively.

The antibody prevalence of the Salmonella-isolated pigs is shown in Table 1. Out of 47 isolation-positive pigs, serum antibodies were detected in 26 pigs $(55.3 \%)$. Twenty-one of 36 pigs (58.3\%) positive for $S$. O4, 12: d: -, 5 of 10 pigs $(50.0 \%)$ positive for $S$. Havana, and none for $S$. 
Table 3. Prevalence of antibodies to LPS of $S$. Typhimurium in pigs

\begin{tabular}{cccc}
\hline & No. of farms & & No. of pigs \\
\cline { 2 - 2 } & Positives/tested (\%) & & Positives/tested (\%) \\
\hline Sows & $19 / 33(57.6)$ & & $77 / 407(18.9)$ \\
Fattening pigs & $25 / 50(50.0)$ & & $118 / 1,091(10.8)$ \\
\hline Total & $35 / 52(67.3)$ & & $195 / 1,498(13.0)$ \\
\hline
\end{tabular}

Table 4. Prevalence of antibodies to LPS of $S$. Typhimurium in pigs

\begin{tabular}{cccc}
\hline \multirow{2}{*}{$\begin{array}{c}\text { Age } \\
\text { (months) }\end{array}$} & \multicolumn{2}{c}{ No. of pigs } & $\begin{array}{c}\text { Positive } \\
\text { rates }(\%)\end{array}$ \\
\cline { 2 - 3 } 1 & Tested & Positives & 0 \\
2 & 140 & 0 & $0^{\mathrm{a} *}$ \\
3 & 234 & 4 & $1.7^{\mathrm{a}}$ \\
4 & 118 & 4 & $3.4^{\mathrm{a}}$ \\
5 & 141 & 16 & $11.3^{\mathrm{b}}$ \\
6 & 147 & 31 & $21.1^{\mathrm{b}}$ \\
\hline Total & 311 & 63 & $20.3^{\mathrm{b}}$ \\
\hline
\end{tabular}

* Significant differences between a and $\mathrm{b}(\mathrm{P}<0.01)$.

Anatum had antibodies to LPS of $S$. Typhimurium. Regarding to pigs positive for $S$. O4, 12: d: -, two of six pigs $(33.3 \%)$, five of seven $(71.4 \%)$, and five of seven $(71.4 \%)$ had antibodies at 4, 5 and 6 months of age, respectively.

Experiment 2: The antibodies to LPS of $S$. Typhimurium were detected in 195 of 1,498 pigs $(13.0 \%)$ and in at least one serum sample on 35 of 52 farms $(67.3 \%$; Table 3$)$. Seventy-seven of 407 sows (18.9\%) and 118 of 1,091 fattening pigs $(10.8 \%)$ had antibodies to LPS of $S$. Typhimurium. The positive rate was $0 \%(0 / 140), 1.7 \%$ (4/234), 3.4\% (4/ $118), 11.3 \%$ (16/141), $21.1 \%$ (31/147), and $20.3 \%(63 / 311)$ at 1 to 6 months of age, respectively (Table 4$)$. The positive rates of pigs at 4 to 6 month of age were significantly higher than those at 1 to 3 month of age $(\mathrm{P}<0.01)$.

Out of 52 farms, serum samples from sows and fattening pigs were collected from 31 farms. The farms were divided into two groups, based on the results of antibody prevalence in sows. One is the group of farms, where antibodies were detected in at least one serum sample of sows (Sow+ group, $\mathrm{n}=18$ ). The other is the group of farms, where no antibody was detected in sows (Sow- group, $n=13$ ). As shown in Fig. 1 , the antibody prevalence in pigs at 5 and 6 months of age was higher in the Sow+ group than in the Sow- group $(\mathrm{P}<0.01)$.

\section{DISCUSSION}

Experiment 1 shows comparison between bacteriological and serological examination under field conditions. Salmonella was isolated from about $30 \%$ of fattening pigs at 4 to 6 months of age. Besides, the antibody-positive rate increased

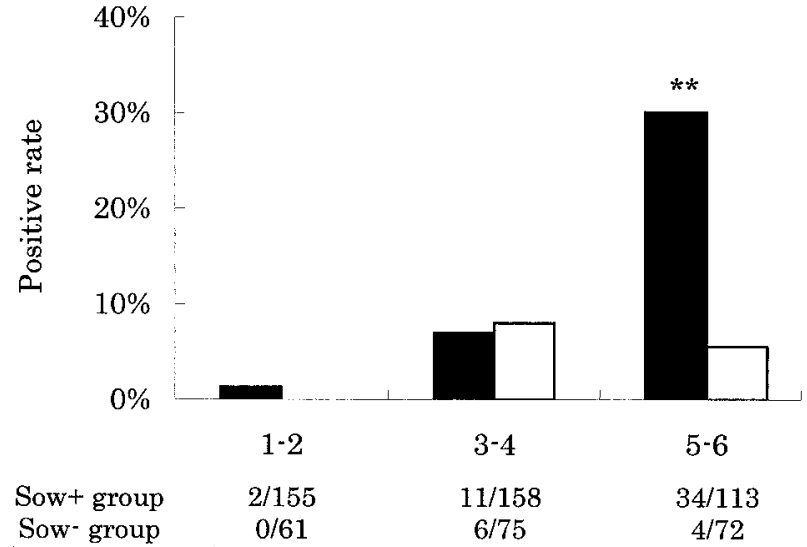

Age in months

Fig. 1. Relationship of antibody prevalence between fattening pigs and sows. The farms were divided into two groups, based on the results of antibody prevalence in sows. Data represented antibody prevalence in pigs on the farms ( $\mathbf{\square}$ : Sow+ group, $\mathrm{n}=18$ ) where antibodies were detected from at least one serum sample in sows, and farms where no antibody was detected in sows ( $\square$ : Sow- group, $\mathrm{n}=13$ ). **: Significant difference between sow + and sow- groups at $\mathrm{P}<0.01$.

in the pigs at $5(31.1 \%)$ and $6(45.5 \%)$ months of age. In the breeding stock, the antibody positive rate was higher in sows $(77.1 \%)$ than in gilts $(52.5 \%)$, though the isolationpositive rate decreased in sows. As the infected pigs intermittently shed Salmonella, it is considered that the antibody-positive rates were higher than the isolation-positive rates in finishers and sows. On the other hand, Salmonella was isolated from $11.9 \%$ in antibody-negative pigs, and $26.3 \%$ pigs at 4 months of age. The antibody response of the pigs may be associated with the time of infection. Nielsen et al. [9] have shown that serological tests are not to be used on individual pigs. The serological examinations may be useful to monitor Salmonella prevalence in pig herds.

Regarding serovars of Salmonella, 58\% of isolation-positive pigs for $S$. O: 4,12: d: - and $50 \%$ of those for $S$. Havana had antibodies to LPS of $S$. Typhimurium. In the pigs experimentally infected with $S$. Typhimurium, $S$. Livingstone, $S$. Goldcoast, $S$. Panama, or $S$. Brandenburg, efficiency of mixed ELISA to monitor $S$. Typhimurium or $S$. Brandenburg was reported [12]. The O-antigens of $S$. Typhimurium, used as ELISA antigen in the present study, consisted of O: 1, 4, 5, and 12. So, the pigs infected with $S$. O: 4,12: d: - can acquire the antibodies to LPS of $S$. Typhimurium, as it reacts to a part of LPS of $S$. Typhimurium as common antigens. On the other hand, the sera from pigs infected with $S$. Havana might react to O: 1 of $S$. Typhimurium as common antigens. Also, it is considered that the positive pigs, that were in older stages such as gilt or sow, have previously been infected with $\mathrm{O} 4$ group of Salmonella. Further investigation is needed to clarify this point. As pre- 
viously described in the experimental infections [9, 12], the antibody prevalence in pigs may also be associated with serovars of the isolates from them under field conditions.

Salmonella was not isolated from any pig below 3 month of age in the bacteriological examinations. In the results of serological examinations, however, positive results were obtained in six pigs at 3 months of age. Salmonella was isolated from pigs at 4 months of age or older, and seropositive rates to LPS of $S$. Typhimurium increased from 5 months of age. Most isolation-positive pigs at 5 to 6 months of age have antibodies to LPS of $S$. Typhimurium, but those at 4 months of age did not always have antibodies to LPS of $S$. Typhimurium. In the herd, transmission of Salmonella occurred mainly in the pigs between 4 to 5 months of age. The seropositive pigs at 3 months of age may be false positive due to some factors in the sera. Beside, experimentally infected pigs were intermittently shedding organisms and some of pigs stopped its shedding within a few weeks [12]. Further studies are being made to clarify whether young seropositive pigs play a role as a reservoir.

In the previous reports in Japan, 19, 17, and 12 serovars were isolated from apparently healthy pigs in the 1970s, 1980s, and in 1998, respectively [7, 17]. The isolation rates of Salmonella belonging to serovar O4 group were $68.1 \%$, $58.7 \%$, and $58.6 \%$ in the 1970 s, 1980 s and in 1998 , respectively $[7,17]$. Furthermore, the isolation rates of Salmonella belong to serovar O4 group were $51.4 \%$ and $88.1 \%$ of pigs in disorder [1] or diarrhea [2], respectively. Thereby, our results in Experiment 2 may partially show the Salmonella prevalence of pigs in Japan. The antibodies to LPS of $S$. Typhimurium were found among $13.0 \%$ of pigs on $67.3 \%$ of farms. The antibody prevalence increased in pigs at 4 to 6 months of age $(11.3,21.1$, and $20.3 \%$, respectively). In Japan, Salmonella was isolated from $5.7 \%(98 / 1,717)$ and $2.3 \%(58 / 2,511)$ of apparently healthy pigs in slaughterhouses in the late 1980s and on farms in 1998, respectively [7, 17]. Experiment 1 shows that the antibody-positive rate was higher than the isolation positive rate. Our results indicated that Salmonella does not seem so prevalent in pigs though it is widely prevalent among pig farms.

Experiment 2 shows that there is no difference of antibody prevalence between sows $(18.9 \%)$ and pigs of 5 $(21.1 \%)$ to $6(20.3 \%)$ months of age. Van der Wolf et al. [15] have reported that antibody prevalence was higher in sows than in finisher pigs. They have shown that the antibody prevalence of finisher and sows in 1999 was $24.5 \%$ and $60.4 \%$, respectively. As ELISA for detection of antibody to mixed LPS (O: 1, 4, 5, 6, 7, and 12) of Salmonella (mixed ELISA) was used in their reports, it is difficult to compare actually their results with ours.

On the farms with antibody-positive sows, antibodies were highly prevalent among pigs of 5 to 6 months of age. Previous investigations showed that piglets have been infected with Salmonella from sows [3, 5, 6, 11]. However, Salmonella was rarely isolated from apparently healthy sows on the farms [7]. Low antibody prevalence was observed among pigs of 1 to 4 months of age, when piglets were usually weaned and mingling. The frequency of infection of suckling pigs with Salmonella from contaminated feces shed by sows continuously or intermittently is obscure.

The present study showed that antibody detected with LPS of $S$. Typhimurium was prevalent among pig farms and high antibody prevalence was observed in some herds. Salmonella infection in apparently healthy pigs indicated the potential risk for food-borne diseases. It is considered that transmission and distribution of Salmonella to pig herds occurred by wild carrier animals and pigs, contaminated environments, and transmission vectors such as feed, boots, vehicles and so on [16]. It is important to recognize the Salmonella prevalence on pig farms and to practice the health management. We are now continuing to survey Salmonella infection among Japanese pigs.

\section{REFERENCES}

1. Akiba, M., Ohya, T., Mitsumori, M., Samejima, T. and Nakazawa, M. 1996. Serotype of Salmonella choleraesuis subsp. Choleraesuis isolated from domestic animals. Bull. Natl. Inst. Anim. Health 102\&103: 43-48.

2. Asai, T., Otagiri, Y., Osumi, T., Namimatsu, T., Hirai, H. and Sato S. 2002. Isolation of Salmonella from diarrheic feces of pigs. J. Vet. Med. Sci. 64:159-160.

3. Dahl, J., Wingstrand, A., Nielsen, B. and Baggesen, D. L. 1997. Elimination of Salmonella typhimurium infection by the strategic movement of pigs. Vet. Rec. 140: 679-681.

4. D'Aoust, J. -Y. 1989. Salmonella. pp. 327-445. In: Foodborne Bacterial Pathogens (Doyle, M. P. ed.), M. Dekker, Inc., New York.

5. Fedrka-Cray, P. J., Harris, D. L. and Whipp, S. C. 1997. Using isolated weaning to raise Salmonella-free swine. Vet. Med. 92: 375-382.

6. Funk, J. A., Davies, P. R. and Nichols, M. A. 2001. Longitudinal study of Salmonella enterica in growing pigs reared in multiple-site swine production systems. Vet. Microbiol. 83: 45-60.

7. Hiratsuka, S., Kamibeppu, M., Hirosawa, T., Futagawa, K. and Fukuyasu, T. 2000. Salmonella incidence and serovars in apparently healthy brood sows. J. Jpn. Vet. Med. Assoc. 53: 533-536 (in Japanese with English summary).

8. Namimatsu, T., Tsuna, M., Imai, Y., Futo, S., Mitsuse, S., Sakano, T. and Sato, S. 2000. Detection of Salmonella by using the colorimetric DNA/rRNA sandwich hybridization in microtiter wells. J. Vet. Med. Sci. 62: 615-619.

9. Nielsen, B., Baggesen, D., Bager, F., Haugegaard, J. and Lind, P. 1995. The serological response to Salmonella serovars typhimurium and infantis in experimentally infected pigs: The time course followed with an indirect anti-LPS ELISA and bacteriological examinations. Vet. Microbiol. 47: 205-218.

10. Nielsen, B., Ekerroth, L., Bager, F. and Lind, P. 1998. Use of muscle fluid as a source of antibodies for serologic detection of Salmonella infection in Slaughter pig herds. J. Vet. Diagn. Invest. 10: 158-163.

11. Nietfeld, J. C., Feder, I., Kramer, T. T., Schoneweis, D. and Chengappa, M. M. 1998. Preventing Salmonella infection in pigs with offsite weaning. Swine Health Prod. 6: 27-32.

12. Van der Winsen R. L., Van Nes, A., Keuzenkamp, D., Urlings, H. A. P., Lipman, L. J. A., Biesterveld, S., Snijders, J. M. A., Verheijden, J. H. M. and Van Knapen, F. 2001. Monitoring of 
transmission of Salmonella enterica serovars in pigs using bacteriological and serological detection methods. Vet. Micrbiol. 80: $267-274$

13. Van der Wolf, P. J., Bonger, J. H., Elbers, A. R. W., Franssen, F. M. M. C., Hunnenman, W. A., Van Exsel, A. C. A. and Tielen, M. J. M. 1999. Salmonella infections in finishing pigs in the Netherlands: bacteriological herd prevalence, serogroup and antibiotic resistance of isolates and risk factors for infection. Vet. Microbiol. 67: 263-275.

14. Van der Wolf, P. J., Elbers, A. R. W., Van der Heijden, H. M. J. F., Van Schie, F. W., Hunnenman, W. A. and Tielen, M. J. M. 2001. Salmonella seroprevalence at the population and herd level in pigs in the Netherlands. Vet. Microbiol. 80: 171-184.
15. Van der Wolf, P. J., Wolbers, W. B., Elbers, A. R. W., Van der Heijden, H. M. J. F., Koppen, J. M. C. C., Hunnenman, W. A., Van Schie, F. W. and Tielen, M. J. M. 2001. Herd level husbandry factors associated with the serological Salmonella prevalence in finishing pig herds in the Netherlands. Vet. Microbiol. 78: 205-219.

16. Schwartz, K. J. 1999. Salmonellosis. pp. 535-551. In: Diseases of Swine 8th ed (Straw, B. E., D'Allaire, S., Mengeling, W. L. and Taylar, D. J. eds.), Iowa State University Press, Iowa.

17. Yoshida, T., Takahashi, I. and Sawada, T. 1995. Incidence and serotypes of Salmonella in apparently healthy swine at slaughterhouses in Japan between 1975 and 1989. Jpn J. Bacteriol. 50: 537-545 (in Japanese with English summary). 